\title{
訓練用シミュレータのための高速過渡安定度 計算手法の開発と適用
}

$\begin{array}{llllll}\text { 正 員 久 } & \text { 和 } & & \text { 進 } & \text { (北陸電力) } \\ \text { 正 員 } & \text { 吉 } & \text { 田 } & \text { 忠 } & \text { 美 } & \text { (北陸電力) } \\ \text { 正員 小 } & \text { 俣 } & \text { 和 } & \text { 也 } & \text { (東 } & \text { 芝) } \\ \text { 正 員 湯 } & \text { 朝 } & \text { 真 } & \text { 司 } & \text { (東 } & \text { 芝) } \\ \text { 正 員 三田村 } & \text { 謙 } & \text { 一 } & \text { (東 } & \text { 芝) }\end{array}$

\section{Development and Application of Fast Transient Stability Calculation Method for a Power System Training Simulator}

Susumu Kyuwa, Member, Tadayoshi Yosida, Member (Hokuriku Electric Power Co.), Kazuya Omata, Member, Shinji Yuasa, Member, Kenichi Mitamura, Member (Toshiba Corp.)

Various stabilizing equipments have been installed in modern power systems to enhance power system stability and its stabilizing algorithms have become more complicated ${ }^{(3)}$.

Most of training simulators, however, simulate a power system by performing power flows and frequency deviation calculations ${ }^{(2)}$. Since these simulators ignore dynamics of individual generators, it is impossible to simulate power swings and out-of-step phenomena which are closely connected with these equipment's actions. To simulate these actions automaticaly in the training simulator, a transient stability calculation program must be incorporated.

There are two methods. In one method, a transient stability calculation program is linked to a conventional training simulator using an event sequence file and called every time it is required ${ }^{(4 \times 5)}$. In the other method, a training simulator involvs a transient stability calculation program itself and simulates the generator dynamics and stabilizing equipment continuously ${ }^{(6)}$. However, to adopt the latter method, a transient stability calculation program that can simulate power swings in real time must be developed. The application of this method to a large power system with more than 100 generators has not been reported so far.

This paper presents a transient stability calculation method which can simulate a large power system with more than 100 generators faster than real phenomena, and it's application to a training simulator.

\section{キーワート゚：訓練用シミュレータ，過渡安定度計算，モデリング，並列処理，マルチプロセッサ}

\section{1.まえがき}

近年, 社会生活・経済活動の電力依存度が増大し, 電力 の安定供給が社会的に重要視されている。また，電力系統 はますます大規模・複雑化しており，これを安定かつ経済 的に運用するための系統運用業務は高度化する一方であ る。これに伴い，系統運用者の責務は，格段に重要性を増 してきて抒り，特に系統事故が発生したときには泠静・沈 着な判断力が要求される。これに対処するためには, 系統 運用者の日ごろの訓練が重要であり，これにはシミュレー 夕による訓練が有効であることが認識されている。この訓
練用シミュレータは, 電力系統の平常時, 事故時および復 旧時の挙動をリアルタイムで模擬するもので，あらかじめ 設定されたシナリオに対してだけではなく，訓練者の操作 にも応答しなければならない。

現在まで, 訓練用シミュレータは国内・外で数多く開発 されているが，その活とんどは潮流計算と周波数動摇計算 を交互に行って，電力系統の挙動を模擬するものであっ $た^{(2)}$ 。この模擬方法では, 電力系統を一つの等価発電機と して取り扱っているため，発電機間に発生する脱調現象を 模擬することはできない。

一方, 最近の電力系統には, 系統事故による脱調現象の 
進展を防止するため，脱調分離リレーをはじめとするいろ いろな系統安定化装置が導入されている。そして，その動 作原理は複雜化する一方である(3)。これに伴い，実系統に 即した系統模擬を行うためには, 系統安定化装置の応動を 模擬しなければならない。しかしながら, 従来タイプのシ ミュレータで系統安定化装置の応動を模擬しょうとする と,トレーナが訓練前にその応動を予測し，訓練シナリオ に組み込まなければならない。電力系統が大規模化し，系 統安定化装置の動作原理も複雑化した今日, 各種の系統事 故による安定化装置の応動をあらかじめ予測することは非 常に困難である。この結果, 系統安定化装置の動作をシミ ユレータで自動的に模擬することが要求される。この要求 を満足するためには，シミュレータに個々の発電機の動特 性を計算できる過渡安定度計算プログラムを内蔵しなけれ ばならない。

これを実現する方法として，次の二つが提案されてい る。一つは, 過渡安定度計算プログラムと従来型シミュレ ータをイベントシーケンスファイルで結合する方法であ $る^{(4)(5)}$ 。この方法では, 訓練シナリオ中の事故に対する安 定度が, 過渡安定度計算プログラムによりチェックされ, 脱調分離リレーなどの応動結果がイベントシーケンスファ イルに出力される。シミュレータ側ではその結果を取り込 み訓練シナリオに追加する。この間，系統模擬は休止状態 となり, 安定度計算に時間がかかる場合は, 臨場感の高い 訓練は不可能となる。

もう一つの方法は, 潮流計算と周波数動摇計算を過渡安 定度計算に直接置き換える方法で, 脱調分雑リレーなどの 系統安定化装置の動作ロジックを組み込めば，中断のない 臨場感の高い訓練が可能になる ${ }^{(6)}$ 。しかしながら，この方 法では実際の現象より高速に過渡安定度計算を実行する必 要があり，100 発電機を超える大規模系統に適用された例 はない。

本論文では, 100 発電機以上の大規模系統の過渡安定度 計算を、リアルタイム以上の速度で計算可能な高速過渡安 定度計算手法(1) とそれを適用した訓練用シミュレータに ついて報告する。開発したシミュレータは，前述した後者 のアプローチ，すなわち潮流計算と周波数動摇計算を過渡 安定度計算に置き換える方法をとっているので, 臨場感の 高い訓練を実施できる。

以下, 第 2 章で㹥要求される過渡安定度計算の速度と精 度について説明する。そして, 第 3 章では高速過渡安定度 計算手法について，第 4 章ではその手法の訓練用シミュレ 一タへの適用方法についてそれぞれ説明する。そして最後 に, 第 5 章で開発したシミュレータのテスト結果を示す。

\section{2. 過渡安定度計算の要求速度と精度}

電力系統の安定度を計算するためには，発電機やその制 御系の動特性を表す非線形微分方程式と，送電系統を表す 非線形代数方程式を同時あるいは交互澥く必要がある。 従来より，系統計画や運用に適用されてきた過渡安定度計
算プログラムでは, 発電機は Park の詳細モデルを用い, AVR，ガバナなどの制御系も実ハードに即した詳細モデ ルを使用している。このため, 発電機 1 台当たりの微分方 程式の数は 20〜30 次元となり, 時定数は $10 \mathrm{~ms}$ 程度のも のも存在する。これにより, 大規模系統の過渡安定度計算 は, 大型計算機を用いても実現象の 10 倍以上の計算時間 を必要とする。

一方, 訓練用シミュレー夕は, 事故発生時の電力系統の 挙動を訓練者にリアルタイムで伝えなければならないた め, 系統計画や運用への適用とは異なり, 計算のリアルタ イム性が第一に要求される。

シミュレータに適用する過渡安定度計算プログラムに要 求される性能をまとめると次のようになる。

(i) 過渡安定度計算の前後処理も考えて実現象の 1.5〜2 倍の計算速度であること。

(ii) 訓練者から見た系統特性が実系統と一致するこ と。すなわち, 安定/不安定および動摇の傾向がお预むね 詳細モデルを用いた過渡安定度計算結果と一致すること。

\section{3. 高速過渡安定度計算手法}

訓練用シミュレータで対象とする電力系統は，発電機数 約 100 台, 母線数約 400 の大規模系統なので, 通常のモデ リングや計算処理方法では前述した要求性能を満足するこ とはできない。

そこで，次に示す四つの方法を組み合わせることによ り, シミュレータに適用可能な過渡安定度計算プログラム を実現する。

（i）インプリシットな台形積分法をベースとした分割 解法の採用。

（ii）モデリングの工夫による積分刻み幅の拡大と演算 処理量の低減（積分刻み幅の目標は $100 \mathrm{~ms}$ )。

（iii）詳細過渡安定度計算結果との整合性をとるための 発電機制動係数の調整。

（iv）マルチプロセッサ構成のコンピュータを用いた過 渡安定度計算の並列処理。

上述した四つの方法の効果を, 計算の高速化と模擬精度 の維持に分けて評価すると表 1 となる。

以下, (i ) ( iv)の項目について具体的に述べる。

〈3・1〉 計算方法(6) 過渡安定度計算で解かなければ ならない方程式は, (1) 式の発電機動特性を表す非線形微 分方程式と (2) 式の送電系統を表す非線形代数方程式であ る。

表 1 適用手法の効果

Table1. Effect of adopted methods.

\begin{tabular}{l|c|c}
\hline \multicolumn{1}{c|}{ 適 用 手 法 } & 高速化 & 精度維持 \\
\hline 台形積分法 & 0 & 0 \\
\hline モデリングの工夫 & 0 & \\
\hline 制動係数の調整 & & 0 \\
\hline 㫫列処理 & 0 & \\
\hline
\end{tabular}


$\dot{X}=A X+B U$

$U=G(X, V)$

$Y V=I$

$I=H(X)$

ここで, $X:$ 発電機内部位相角などの状態変数,

$U:$ 発電機出力などのインタフェース変数, $V$ :

ノード電圧， $I:$ ノドへの注入電流， $Y:$ ノ

ドアドミタンス行列, $A, B$ : 係数行列, $G$,

$H$ : 非線形関数

過渡安定度計算手法に怯，(1)式と(2)式を交互に解く 分割解法と，(1)式を代数方程式に変換し(2)式と同時に 解く同時解法がある。後者の方法では，ヤコビアン行列が 積分ステップごとに変化するので，LDU 分解に多くの時 間がかかり，高速計算に適していない。一方，前者の方法 では, 系統構成が変化しないかぎり,ノードアドミタンス 行列は定数として取り扱えるので高速計算が期待できる。 そこで，前者の分割解法を採用する。

次に, 数值積分法に関しては, 高速性, 安定度計算に対 する適性面から幾つかの手法が提案されている(77/8)。訓練 用シミュレータでは，高速なシミュレーションを数時間継 続する必要があることから, 高速性とともに数値安定性が 要求される。そこで, 次の理由によりインプリシットな台 形積分法を採用する。

（i） 発電機の動摇（振動波形）を精度良く計算するこ とができる。

(ii) 次数が低く，高速計算に適している。

（iii） 数值安定性が良く，長時間のシミュレーションに 適している。

図 1 にインプリシットな台形積分法をベースとした分割 解法の処理フローを示す。同図に抒いて $\Delta t$ は積分刻み

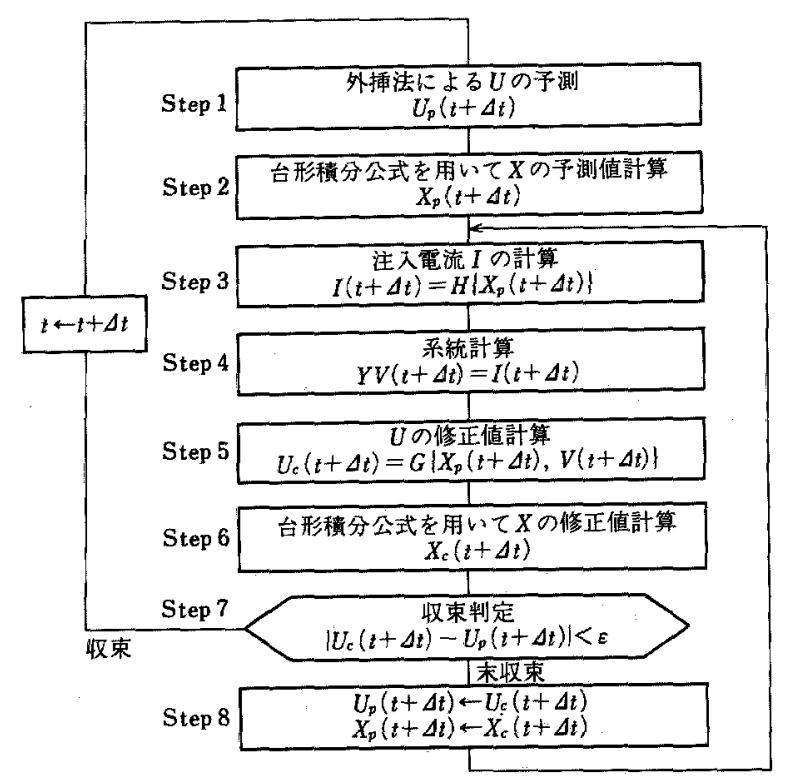

図 1 分割解法の処理フロー

Fig. 1. Flow of partitioned solution method.
幅, $t$ 玩待点のシミュレーション時間である。

〈3・2〉モテリング，積分刻み幅を目標の $100 \mathrm{~ms}$ に するためには，数值安定性加ら考えて $100 \mathrm{~ms}$ 以下の時定 数をもつ動特性を省略する必要がある。これらの特性に は，発電機のダンパ回路，AVRのPSS 回路が含まれる。 また, 計算の中には負荷特性のように綝返し計算の必要な ものも含まれる。そこで, 次のような方法により, 積分刻 み幅の拡大と演算量の低減を図る。

(i ) $100 \mathrm{~ms}$ 以下の時定数をもつ発電機のダンパ回路; AVRのPSS 回路はモデル化しない。これにより失われ る発電機の制動力は, 発電機の制動係数に付加する。制動 係数の調整方法については, 〈3・3〉節で述べる。

（ii） AVR モデル注，模擬すべき周波数領域，すなわ ち, $0 \mathrm{~Hz}$ から電力動摇の周波数領域である数 $\mathrm{Hz}$ 程度ま で, 詳細モデルと周波数特性が一致するように低次元化す る。

（iii）ガバナタービンモデルは，安定度に対する影響度 が小さいことから，定常特性を合わせることを基本に，詳 細モデルの応答特性を考慮して, 一次遅れあるいは二次遅 れ回路で模擬する。

（iv）負荷特性計算は, 絽返し計算の必要ない近似計算 法を用いる。

（1）発電機モデル（3)式に示すように，ダンパ回 路を無視した過渡モデルを適用する。ダンパ回路の制動効 果は，前述したように発電機の制動係数に付加する。ま た，過渡凸極性は，収束計算が必要になることから考慮し ない。なお，全体の演算量を少なくするため，下位系の小 容量水力機は, $X_{d}^{\prime}$ 背後電圧一定モデルで模擬している。

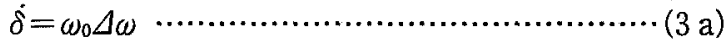

$$
\begin{aligned}
& \Delta \dot{\omega}=\frac{1}{M}\left\{P_{m}-P_{e}-D\left(\Delta \omega-\Delta \omega_{c o l}\right)\right\} \\
& \dot{e}_{q}^{\prime}=\frac{1}{T_{d 0}^{\prime}}\left(E_{f d}-E_{I d}\right) \\
& \dot{e}_{d}^{\prime}=\frac{1}{T_{q 0}^{\prime}}\left(-E_{1 q}\right) \\
& E_{I d}=e_{q}^{\prime}+\left(X_{d}-X_{d}^{\prime}\right) i_{d} \\
& E_{1 q}=e_{d}^{\prime}+\left(X_{q}-X_{q}^{\prime}\right) i_{q}
\end{aligned}
$$

ここで, $\delta:$ 内部位相角, $\Delta \omega$ : 角速度偏差, $e_{d}^{\prime}$, $e_{q}^{\prime}:$ 内部電圧の $d, q$ 軸成分, $P_{m}$ : 発電機への 機械入力, $E_{f d}$ : 界磁電圧, $P_{e}$ : 発電機出力, $i_{d}$, $i_{q}$ : 電流の $d, q$ 軸成分, $\omega_{0}$ : 定格角速度, $\Delta \omega_{c o I}$ : 発電機の平均角速度偏差, $M$ : 慣性定 数, $D$ : 制動係数, $T_{d 0}^{\prime}$ : 界磁開路時定数, $T_{q 0}^{\prime}$ : $q$ 軸の開路時定数, $X_{d}, X_{q}: d, q$ 軸の同時リ アクタンス, $X_{d}^{\prime}: d$ 軸過渡りアクタンス, $X_{q}^{\prime}$ : $q$ 軸過渡リアクタンス $\left(=X_{\alpha}^{\prime}\right)$

(2）AVRモデル AVRの構成を図2に示す。こ のモデルは，ゲイン $K_{1}, K_{2}, K_{3}$ と時定数 $T_{1}, T_{2}$ を調整 することにより，模擬すべき周波数領域（0～数 $\mathrm{Hz}$ 程度） でオリジナルな詳細モデルと，周波数特性をほほ一致さ せることができる。特に，AVRの応答特性として重要な 
定常ゲインとカットオフ周波数は詳細モデルと一致する。 PSS が付いている場合は，その制動効果を発電機の制 動係数に付加することにより等価的に模擬する。

（3）ガバナタービンモデル 火力機用ガバナタービ ンモデルを図 3 に, 水力機用モデルを図 4 に示す。火力機 用は，周波数変化に対して高速に応答する高圧タービン部 と, 再熱器を介してゆっくり応答する中／低圧タービン部 に大きく分けられるので, 図 3 に示すように二つの一次遅 れ回路とゲインおよび低值優先回路でモデル化する。一 方, 水力機用は, 火力機のような応答速度の異なる系が存 在しないので, 一次遅れ回路とゲインおよび低值優先回路 でモデル化する。

（4）負荷特性 負荷の電圧特性は, 計算量の最も少 ない定インピーダンス特性を用いる。負荷の周波数特性に 関しては，系統分離などの大外乱による周波数上昇や周波 数低下を高精度に模擬したいことから，全体の負荷特性は (4)式に示す周波数特性を考慮した定インピーダンス特性 とする。

$$
\left.\begin{array}{l}
P_{L}=P_{L 0}\left(1+k_{P} \Delta f_{L}\right)\left(\frac{\left|V_{L}\right|}{\left|V_{L 0}\right|}\right)^{2} \\
Q_{L}=Q_{L 0}\left(1+k_{Q} \Delta f_{L}\right)\left(\frac{\left|V_{L}\right|}{\left|V_{L 0}\right|}\right)^{2}
\end{array}\right\}
$$

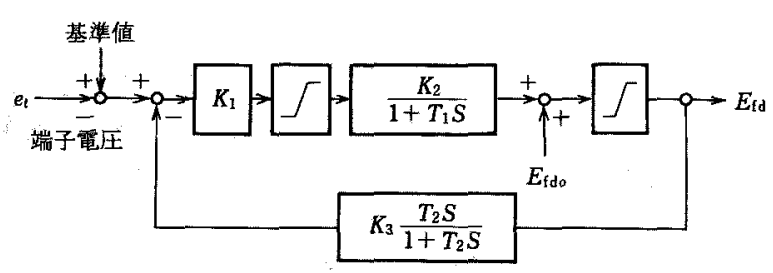

図 2 AVR モデルの構成図

Fig. 2. Block diagram of AVR model.

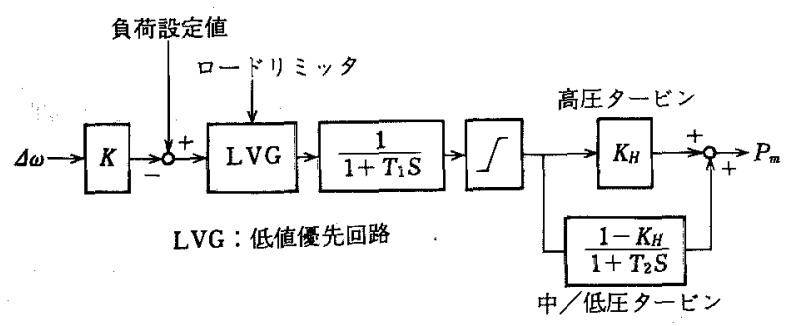

図 3. 火力機用ガバナタービンモデル

Fig. 3. Block diagram of governor turbin model for thermal generator.

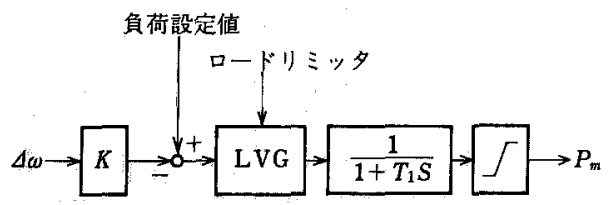

図 4 水力機用ガバナモデル

Fig. 4. Block diagram of governor model for hydroelectric generator.
ここで， $P_{L 0}, Q_{L 0}$ : 有効および無効電力の初期

值, $V_{L}, V_{L 0}$ : ノ一ド電圧とその初期值, $\Delta f_{L}$ :

ノード電圧の周波数偏差， $K_{P}, K_{Q}$ : 有効および

無効電力の周波数特性定数

通常, 負荷の周波数特性を考慮すれば，負荷特性は非線 形となり，系統計算 $(Y V=\mathrm{I})$ の各ステップごとに収束計 算が必要になる。そこで，1積分ステップ前の系統周波数 を用いた繰返し計算の必要ない近似計算法を適用する。以 下にその計算手順を示す。

（S 1）ノードアドミタンス行列に負荷の定インピーダ ンス分をうめ込む。

（S 2） 1 積分ステップ前のノード電圧と周波数を用い て，(4)式の負荷特性と定インピーダンス負荷特性間の注 入電流の差分 $\Delta I_{L}$ を( 5 ) 式より計算する。

（S 3） $\Delta I_{L}$ を補正量として，対象ノードの注入電流に 加え，系統計算 $(Y V=\mathrm{I})$ を行うことにより，負荷の周波 数特性を考慮した系統電圧を求める。

$$
\begin{aligned}
\Delta I_{L}(t)= & P_{0} \frac{k_{P} \Delta f(t-\Delta t)}{V_{L}^{*}(t-\Delta t)}\left(\frac{\left|V_{L}(t-\Delta t)\right|}{\left|V_{L 0}\right|}\right)^{2} \\
& -j Q_{0} \frac{k_{Q} \Delta f(t-\Delta t)}{V_{L}^{*}(t-\Delta t)}\left(\frac{\left|V_{L}(t-\Delta t)\right|}{\left|V_{L 0}\right|}\right)^{2}
\end{aligned}
$$

通常，系統周波数は，発電機の慣性などにより積分刻み 幅に比べてゆっくり変動するので，この模擬方法でも精度 は十分であると考えられる。

〈3・3〉 発電機制動係数の調整 積分刻み幅を目標の $100 \mathrm{~ms}$ にするために, 発電機のダンパ回路とAVRの PSS 回路はモデル化していない。これらの模擬を省略す ると, 発電機の制動力が低下し, 動摇時のダンピングが悪 化する。このため, ダンパ回路と PSS 回路の制動効果を 発電機の制動係数に付加することで精度低下を防止する。

図 5 に制動係数 $D$ のチューニング手順を示す。チュー ニングの目的は，与えられた複数の詳細過渡安定度計算結 果と安定/不安定および動摇の傾向を合わせることにあ る。これにより得られた制動係数を使用することにより， チューニングに使用したケース以外でも妥当な結果を得る ことができる。

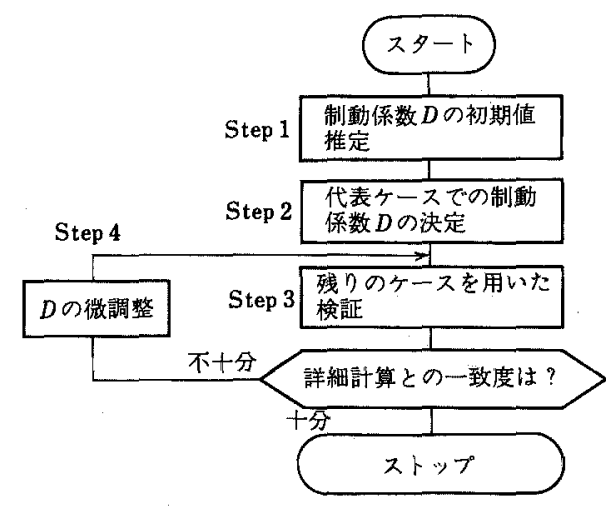

図 5 ，制動係数の調整手順

Fig. 5. Tuning procedure of damping coefficient. 
まず図 5 の（Step 1）で，ダンパ回路と PSS の制動効 果を見積もり，その総和をチューニングの初期値とする。 通常, ダンパ回路の制動効果は小さく，数 puといわれて

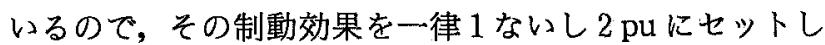
ても問題ない。一方, PSS の制動効果は, ダンパ回路に 比べて大きく，発電機や対象とする動摇モードによって変 化するので，経験的な值を用いることはできない。そこ で，一機対無限大母線系統を対象とした動態安定度ブロッ ク図から PSS の制動効果を推定する(9)。その手順は以下 となる。

（S 1）PSS のついた発電機を対象に，系統を一機対無 限大母線系統に縮約し，線形化した動態安定度ブロック図 を得る。

（S 2） 周波数応答法を用いて, PSS 回路がある場合と ない場合の制動トルク係数の周波数特性を求める。

（S 3）詳細過渡安定度計算結果などから対象発電機の 主動摇モードの振動周波数を求める。

（S 4）この振動周波数に対して，PSSのありなしによ る制動トルク係数の差分を求め，その值を制動効果の初期 值とする。

図 6 はこの力法による制動効果の推定例である。対象発

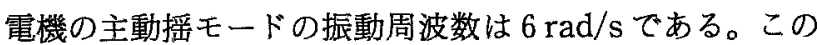
振動周波数において，PSSがある場合の制動トルク係数

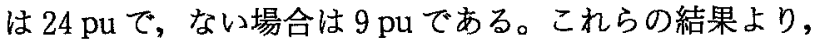

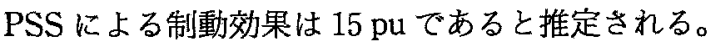

次に図 50 Step 2で，代表ケースを対象に，詳紐過渡 安定度計算結果と動摇傾向が一致するように発電機の制動 係数を調整する。そしてStep $3 て ゙$ ，調整した制動係数を 残りのケースで検証する。もし，詳細計算結果との整合性 が十分でない場合は，Step 4 にて制動係数を微調整する。

〈3・4〉並列処理手法 前述した高速化手法だけでは, 第 2 章で述べた計算速度の要求を満足することはできな い。そこで，マルチCPU 構成のコンピュータシステムを 用いて更なる高速化を図る。これに適用する並列計算手法 を以下に説明する。

（1）微分方程式の並列処理 図 1 の Step 1，2 およ

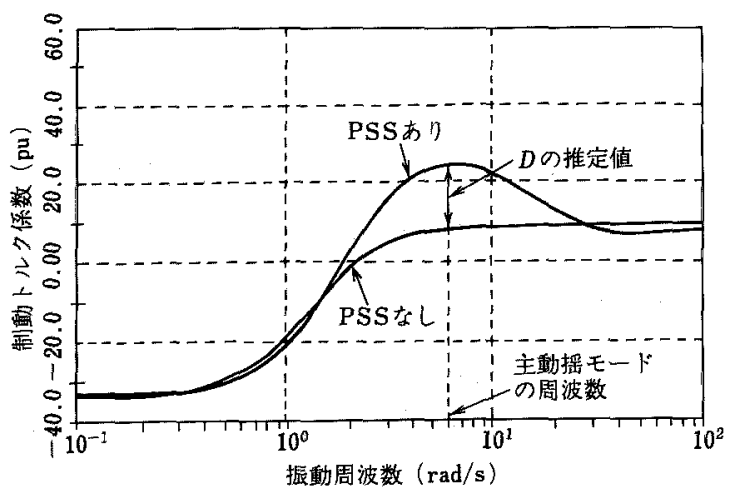

図 6 PSS による制動効果の推定例 Fig. 6. Example of estimated result of damping effect due to a pss.
び 5〜8が微分方程式の求解に対疬する。この処理は，発 電機でとに完全に独立して行うことができるので，処理す る発電機数をプロセッサ間で等しくすることにより最適な 並列処理が可能になる。

(2) 系統方程式 $(Y V=\mathrm{I})$ の並列処理 系統方程式 ( $Y V=\mathrm{I})$ を解くためには, 図 1 の Step 3，4 を処理しな ければならない。これに加えて, 系統構成に変化が生じた 場合は，ノードアドミタンス行列の修正とその LDU 分解 が必要になる。

系統方程式の並列処理方法として幾つかのアルゴリズム が提案されているが，以下の理由により文献(10)，(11)の BDBF (Block Diagonal Bordered Form) アルゴリズム を適用する。

(i) 訓練用シミュレータに適用する計算機システム は, 密結合型マルチプロセッサ構成であり,プロセッサ間 のデータ転送時間は無視できる。

（ii）訓練対象系統の基本構成が放射状である。このた め，系統を分割したときのカットセットブロック（分割さ れた部分系統間を結ぶ連絡ノード群）が小さくなり, 直列 処理部分の演算量が少なくなる。これにより，並列処理の 利得が向上する。

\section{4. 訓練用シミュレータへの適用方法とシステム} 構成

〈4・1〉 シミュレーションモデル＼cjkstart実系統にそくした 訓練を実施するためには，電力系統を構成するすべての要

表 2 シミュレータで模擬される電力系統モデル Table 2. Power system models.

\begin{tabular}{|c|c|c|c|}
\hline \multirow{2}{*}{ 要素 } & \multicolumn{3}{|c|}{ モデルの分類 } \\
\hline & 高速モデル & 中速モデル & 低速モデル \\
\hline \multirow{3}{*}{$\begin{array}{l}\text { 発 電 } \\
\text { プラント }\end{array}$} & 発電機 & 自動 Var 調整 & \\
\hline & ガバナタービン & \multirow[t]{2}{*}{ 自動力率調整 } & \\
\hline & AVR & & \\
\hline \multirow[t]{3}{*}{ 負 荷 } & 周波数特性 & \multirow[t]{3}{*}{ 需要の短周期変化 } & \multirow[t]{3}{*}{ 篅要の長周期変化 } \\
\hline & 電王特性 & & \\
\hline & $\begin{array}{l}\text { 瞬時電圧低下による } \\
\text { 負荷脱落 }\end{array}$ & & \\
\hline $\begin{array}{l}\text { 送電線: } \\
\text { 変压器 }\end{array}$ & \begin{tabular}{|l} 
正相回路の $\pi$ 型等䤄 \\
回路
\end{tabular} & 母線モデル & \\
\hline \multirow[t]{4}{*}{ リレー } & 主/後備保護りレー & 過/不足電压りレー & \\
\hline & 過/不足周波数リレー & \multirow[t]{3}{*}{ 過負荷リレー } & \\
\hline & 脱調分離りレー & & \\
\hline & 電力動摇検出リレー & & \\
\hline \multirow{3}{*}{$\begin{array}{l}\text { ローカル } \\
\text { 自動制御 }\end{array}$} & & 自動再閉路装置 & \\
\hline & & 変王器のタップ制㣤 & \\
\hline & & $\begin{array}{l}\text { スタコンリアクト } \\
\text { ルの投入・開放制御 }\end{array}$ & \\
\hline \multirow{2}{*}{$\begin{array}{l}\text { 中央給電 } \\
\text { 指令所の } \\
\text { 自動制御 }\end{array}$} & & \multirow[t]{2}{*}{$\begin{array}{l}\text { 負荷周波数制御 } \\
\text { (LFFC) }\end{array}$} & $\begin{array}{l}\text { 電力・無効電力 } \\
\text { 制御 (VQC) }\end{array}$ \\
\hline & & & 過負荷解消制御 \\
\hline
\end{tabular}


素を模擬しなければならない。模擬要素には, 発電プラン ト, 負荷, 送電線, 変圧器, 保護りレーおよび中央給電指 令所や発電所などで行われている自動制䘖が含まれる。表 2 は訓練用シミュレータで模擬する要素を示したもので, その応答速度により高速モデル, 中速モデル, 低速モデル に分類されている。この中で, 高速モデルの部分が第 3 章 で述べた高速過渡安定度計算手法により計算される。

〈4・2〉系統模擬方法 表 2 に示したすべての要素を 1 台の計算機システムで模擬することは, 計算処理能力か ら考えて困難である。そこで，2台の計算機システムを適 用した負荷分散システムによりシミュレータを実現する。

図 7 に 2 台の計算機システムを用いた電力系統のシミュ レーションフローを示す。安定度計算用計算機は，訓練管 理・系統模擬用計算機から電力系統モデルや事故シーケン スを受け取り，100 ms 刻みで過渡安定度計算を行い，高 速モデルの応動を計算する。一方，訓練管理・系統模擬用 計算機は，安定度計算用計算機からノード電圧や周波数あ るいは高速モデルの応動結果を受け取り, 中速モデル (2３0 秒間隔の模擬) および低速モデル（1 分あるいはそ れ以上の間隔での模擬）の応動を計算する。これら 2 台の 計算機は，共有メモリーを通して 2 秒間隔でデータを交換

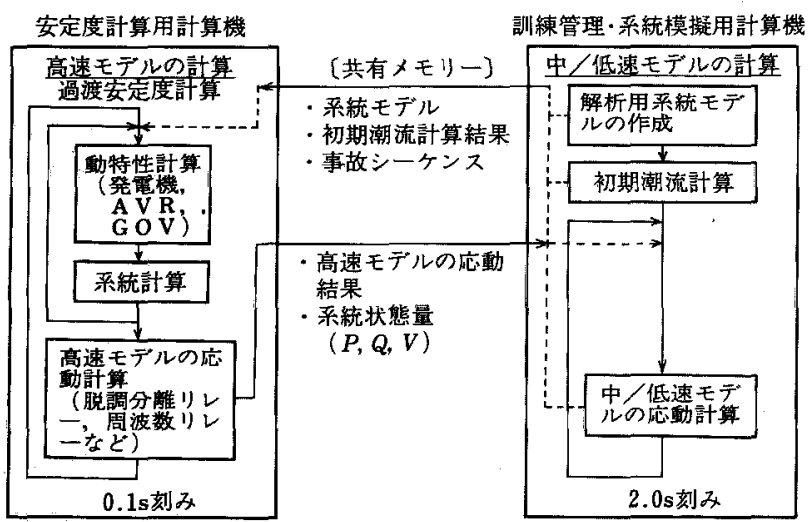

図 7 電力系統のシミュレーションフロー

Fig. 7. Simulation flow of power system.

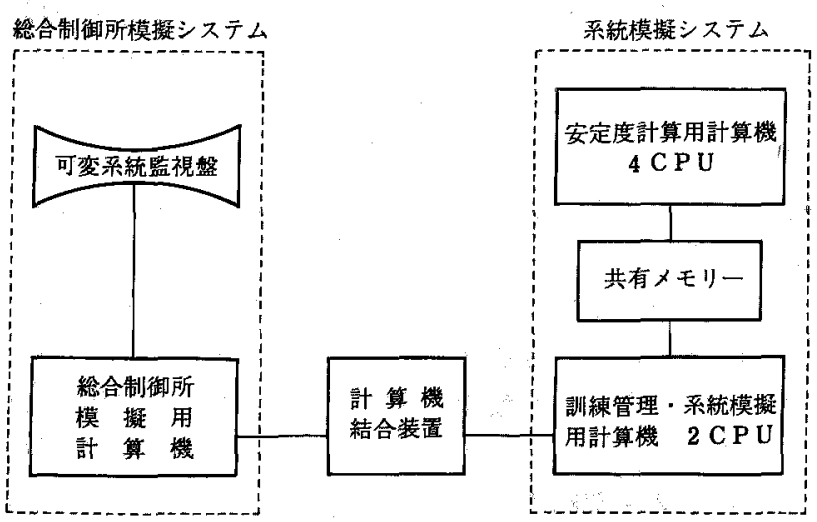

図 8 訓練用シミュレータのシステム構成

Fig. 8. System configuration of simulator.
する。

〈4・3〉システム構成 図 8 に北陸電力の総合制御所 向けに開発した訓練用シミュレータのシステム構成図を示 す。シミュレータは, 訓練対象となる総合制御所を模擬す る総合制御所模擬システムと, 電力系統の挙動を模擬する 系統模擬システムから構成される。

系統模擬システムは，2 台の計算機システムが適用さ れ, 図 7 の流れにより電力系統の挙動を計算する。これら の計算機システムは，マルチプロセッサ構成で, 10 MIPS の処理能力をもつプロセッサを最大 4 台まで実装できる。 図 7, 図 8 に示した安定度計算用計算機は, 4 台のプロセ ッサを，訓練管理・系統模擬用計算機は，2台のプロセッ サをそれぞれ実装している。

総合制御所模擬システムは，実際の総合制御所と全く同 じハードウェア，ソストウェアから構成されている。これ により，臨場感の高い訓練が可能になる。

なお，開発したシミュレータはデータベースの切換えに より，4箇所の総合制御所を模擬することができる。

\section{5. 過渡安定度計算プログラムの検証}

第 3 章で述べた高速過渡安定度計算手法を適用した過渡 安定度計算プログラムの検証結果を示す。検証に用いた系 統モデルは, 訓練対象となる電力系統を模擬したもので, 発電機数が約 100 台，ノード数が約 400 である。

〈5-1〉過渡安定度計算結果 三相短絡事故を対象に 事故点, 事故継続時間および潮流条件を変えて詳細過渡安 定度計算を行い，20のテストケースを用意した。そのう ちの1ケースを代表ケースとしてく3・3〉節で述べた方法に より発電機の制動係数を調整した。図 5 の流れに従って, 各発電機の制動係数をチューニングした結果, 3 回の調整 で望ましいシジレーション結果が得られた。図 9 に調整 後の制動係数を用いた計算結果と詳細過渡安定度計算結果 とを比較する。同図より, 動摇周期, 減衰の傾向ともほほ 一致していることがわかる。

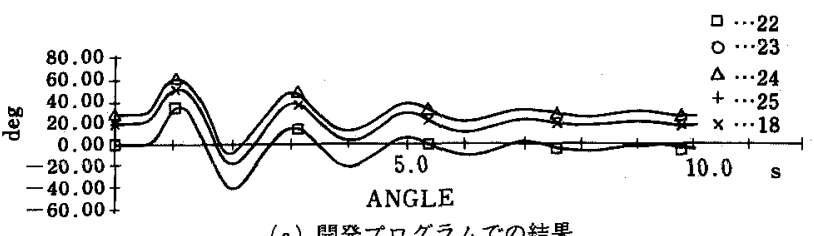

(a) 開発プログラムでの結果

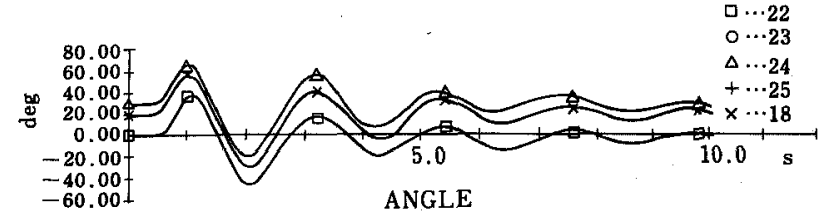

(b) 詳細プログラムでの結果

図 9 詳細過渡安定度計算結果との比較 (制動係数の調整に用いたケース)

Fig. 9. Comparison with result of detailed transient stability calculation for a tuning case. 


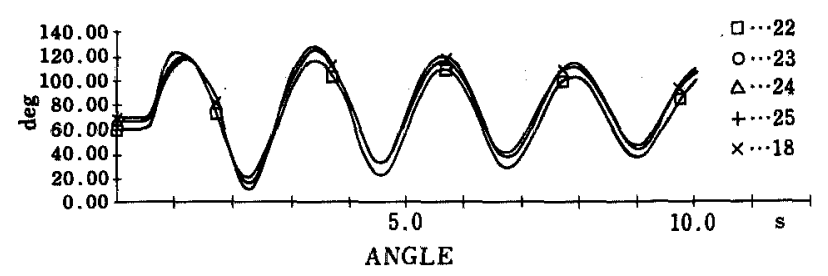

(a) 開発プログラムでの結果

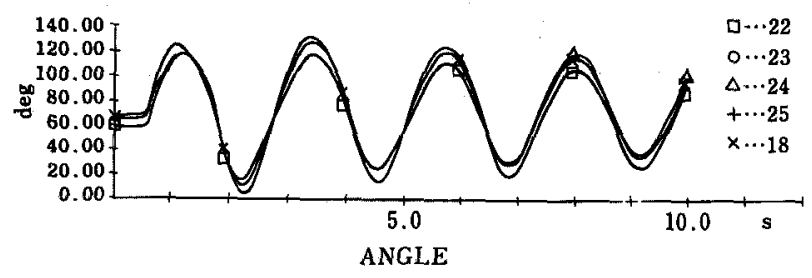

(b) 詳細プログラムでの結果

図 10 詳細過渡安定度計算結果との比較 (検証ケース)

Fig. 10. Comparison with result of detailed transient stability calculation for a verification case.

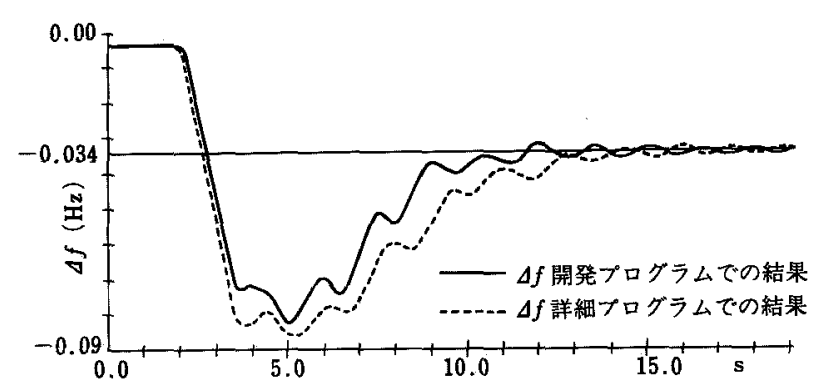

図 11 周波数変動計算結果

Fig. 11. Frequency deviation calculation result.

次に，制動係数の調整結果を残りの 19 ケースに適用し， その妥当性を検証した。幾つかのケースで制動力の小さな 差がみられたが，詳細計算結果との一致度は活济満足でき るものであった。一例として，安定限界に近いケースの比 較結果を図 10 に示す。詳細計算結果と比べると,ダンピ ングが若干良くなっているが，訓練用シミュレータへの適 用に対しては十分な精度であると考えられる。

〈5・2〉周波数变動計算結果図 $11 に 1,000 \mathrm{MW} の$ 電源脱落時のシミュレーション結果を詳細計算結果と比較 する。同図からわかるように，周波数の最終状態值は詳細 計算結果と一致しているが, 最大低下量には多少の差が見 られる。これは，ガバナタービンモデルの低次元化の影響 であるが，過渡安定度計算結果の場合と同様に，訓練用シ ミュレータへの適用に対しては十分な精度であるといえ る。

〈5・3〉計算時間 表 3 に訓練用シミュレータの対象 としている電力系統の系統規模を示す。表 4 に, 表 3 の電 力系統に対する過渡安定度計算時間の実測結果を示す。対 象計算機は〈4・3〉節で述べたマルチプロセッサ構成の計算 機システムである。

表 4 において，ケース 1 は系統事故がない場合の 2 秒間
表 3 対象系統規模

Table 3. Size of power system.

\begin{tabular}{|c|c|c|c|c|c|}
\hline \multirow{3}{*}{ 総合制御所 } & \multicolumn{5}{|c|}{ 対象紊統規模 } \\
\hline & \multicolumn{2}{|c|}{ 発電機数 } & \multirow[t]{2}{*}{ 負荷の数 } & \multirow[t]{2}{*}{ ノード数 } & \multirow[t]{2}{*}{ ブランチ数 } \\
\hline & 過渡モデル & $X_{d}^{\prime}$ モデル & & & \\
\hline$A$ & 53 & 24 & 160 & 324 & 449 \\
\hline$B$ & 57 & 22 & 178 & 355 & 498 \\
\hline C & 67 & 15 & 147 & 354 & 445 \\
\hline D & 60 & 41 & 163 & 387 & 528 \\
\hline
\end{tabular}

表 4 計算時間

Table 4. Calculation time.

\begin{tabular}{c|c|r|r|r|r}
\hline \multirow{2}{*}{ 条件 } & \multirow{2}{*}{ 計算時間(秒) } & \multicolumn{4}{|c}{ 総合制御所 } \\
\cline { 3 - 6 } & \multicolumn{1}{c|}{$A$} & \multicolumn{1}{c|}{$B$} & \multicolumn{1}{c}{$C$} & \multicolumn{1}{c}{$D$} \\
\hline \multirow{4}{*}{ ケース 1 } & 詳細計算 $(X)$ & 94.90 & 102.31 & 104.10 & 130.71 \\
\cline { 2 - 6 } & 開発直列 $(Y)$ & 2.65 & 2.82 & 2.97 & 3.48 \\
\cline { 2 - 6 } & 開発並列 $(Z)$ & 0.97 & 0.98 & 1.07 & 1.10 \\
\hline \multirow{4}{*}{ ケース2 } & 詳細計算 $(X)$ & 97.89 & 110.95 & 111.96 & 136.10 \\
\cline { 2 - 6 } & 開発直列 $(Y)$ & 3.79 & 4.06 & 4.20 & 4.60 \\
\cline { 2 - 6 } & 開発並列 $(Z)$ & 1.34 & 1.40 & 1.46 & 1.50 \\
\hline
\end{tabular}

表 5 系統分割結果

Table 5. Result of network partitioning.

\begin{tabular}{c|c|c|c|c|c}
\hline \multirow{2}{*}{$\begin{array}{c}\text { 紛 合 } \\
\text { 制 御 所 }\end{array}$} & \multicolumn{5}{|c}{ 各部分系統のノード数 } \\
\cline { 2 - 6 } & 1 & 2 & 3 & 4 & $C N$ \\
\hline$A$ & 81 & 79 & 82 & 74 & 8 \\
\hline$B$ & 88 & 85 & 87 & 89 & 6 \\
\hline$C$ & 83 & 93 & 84 & 86 & 8 \\
\hline$D$ & 96 & 98 & 90 & 95 & 8 \\
\hline
\end{tabular}

のシミュレーションに要する計算時間, ケース 2 は送電線 に三相短絡事故（100 ms 後に事故送電線を遮断）を発生 させた場合の計算時間である。また, 詳細計算 $(X)$ 活, 四次のルンゲ・クッタ法と詳細モデルを用いたプログラム により，1台のプロセッサを用いて，10 ms の積分刻みで シミュレーションしたときの計算時間，開発直列 $(Y)$ は, 表 1 中の最初の三つの手法を適用し，1台のプロセッサを 用いて, $100 \mathrm{~ms}$ の積分刻みでシミュレーションした場合 の計算時間, 同並列 $(Z)$ は, 更に, 表 1 の最後の手法を 追加し，4台のプロセッサにより並列処理を実施した場合 の計算時間である。

表 5 は, 開発並列 $(Z)$ のケースを実測するための系統 の分割結果であり, 各部分系統のノード数を均等化し，か つカットセットノード数（表 5 中の $C N$ ）が少なくなるよ うに分割した。

表 4 の結果を要約すると以下となる。

(i) 詳細計算 $(X)$ の結果より, 詳細モデルを用いて, 実現象以上の速度で過渡安定度計算を行うためには，対象 


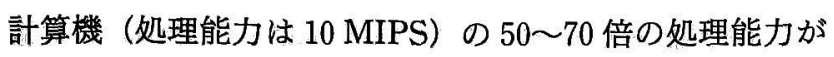
必要になる。

（ii） 台形積分法の適用と制動係数の調整を含むモデリ ングの工夫による高速化率 $(X / Y)$ は, 無事故のケ一スで 35〜40 倍, 事故時のケースで 25〜30 倍である。無事故時 と事故時の高速化率の差は, 台形積分法 1 ステップ当たり の収束回数の相違によるものである。すなわち, 事故が発 生すると, 図 1 中の Step 3 8 の繰返し回数が増加し, ル ンゲ・クッタ法に対する利得が減少する。

（iii）並列処理による高速化率 $(Y / Z)$ は, 無事故時, 事故時ともほほ同じで，2.5３倍である。4台のプロセッ サを使って 4 倍の高速化率とならない原因は, 並列アルゴ リズム自体のオーバヘッドと 4 台のプロセッサを管理する ための計算機システムのOS（オペレーティングシステ ム）のオーバヘッドである。

（iv）表 1 に示した四つの手法を適用することにより， 2 秒間のシミュレーションを $1 \sim 1.5$ 秒で計算することが できる。この結果は, 第 2 章で述べた計算時間の要求をほ 淄淽足している。

以上, $\langle 5 \cdot 1\rangle \sim\langle 5 \cdot 3\rangle$ 節で示した検証結果より, 高速過渡 安定度計算手法の訓練用シミュレータへの適用性が確認で きた。

\section{6.むすび}

本論文では，訓練用シミュレータのための高速過渡安定 度計算手法とそれを適用したシミュレータシステムについ て報告した。提案した高速計算手法は以下の四つの高速化 手法の組合せであり，これにより大規模電力系統のリアル タイム過渡安定度計算が可能になった。

（1）インプリシットな台形積分法をベースとした分割 解法の採用。

（2）モデリングの工夫による積分刻み幅の拡大と演算 処理量の低減。具体的には, 発電機とその制御系モデルの 低次元化，簡略負荷特性計算の適用である。

（3）モデルの低次元化により生じる精度低下を防ぐた めの発電機制動係数の調整。

(4) マルチプロセッサ構成のコンピュータを用いた過 渡安定度計算の並列処理。

テスト結果より，本計算手法を適用したプログラムは, 計算精度を維持しながら，100 発電機，400ノードの電力 系統の過渡安定度計算を, 実現象の 1.5 2 倍のスピード で計算できることが確認された。

本計算手法をべースに開発されたシミュレータは北陸電 力の研修センタに導入され, 初心者から熟練者まで幅広い オペレータの訓練に利用されている。シミュレータの年間 スケジュールは, 初級者の訓練に 3 か月, 中・上級者の訓 練に 6 か月, シナリオ作成に 1 か月, ソフトウェアのメン テナンスに 2 か月が割当てられている。訓練は, 3 人のト レーナが 3 人程度のオペレータを対象に行っており，1回 の訓練は目的により異なるが，1 日から多くて 5 日程度で
ある。

このほか, 本シミュレータは, 実系統で発生した事故の 再現や系統特性の把握にも用いられている。

最後に, 訓練用シミュレータの開発に御援助・御協力し ていただいた北陸電力(株)と(株)東 芝の多くの方々に感 謝します。

(平成 5 年 7 月 15 日受付, 同 5 年 12 月 21 日再受付)

\section{文 献}

（1）久和・吉田・林・小俣・三田村：「並列計算手法を用いたりアルタ 亿公過渡安定度計算ソフトの開発」, 平 3 電気学会電力・エネルギ 一部門大会 (論文 I ) - 12, p. 67

(2) K. Sato, et al.: "Dynamic Simulation of a Power System Network for Dispatcher Training", IEEE Trans. Power Apparatus Syst., PAS-101, No. 10 (1982)

（3）大浦，他：「電源系統の事故波及防止システムの方式と構成」，電 学論 $B, 112,593$ (平 4-7)

(4) G. Zhang \& A. Bose: "Scenario for Operator Training Simulator Using a Transient Stability Program", IEEE Trans. Power Syst., 4, No. 4 (1989)

(5) S. Vadari, et al.: "An Online Implementation of Transient Stability in a Dispatcher Training Simulator", ibid., 6, No. 1 (1991)

(6) K. Saikawa, et al.: "Real Time Simulation System of Largescale Power System Dynamics for a Dispatcher Training Simulator", IEEE Trans. Power Apparatus Syst., PAS-103, No. 12 (1984)

(7) H.W. Dommel \& N. Sato: "Fast Transient Stability Solutions", ibid., PAS-91, No. 4 (1972)

（8）横山・岩本:「電力系統の長時間安定度計算における数值解析手 法に関する考察」, 電学論 B, 110, 465 (平 2-6)

(9) P. Demello \& C. Concordia: "Concepts of Synchronous Machine Stability as Affected by Excitation Control", IEEE Trans. Power Apparatus Syst., PAS-88, No. 4 (1969)

(10) W. L. Hatcher, et al.: "A Feasibility Study for the Solution of Transient Stability Problems by Multiprocessor Structures", ibid., PAS-96, No. 6 (1977)

(11) J. Fong \& C. Pottle: "Parallel Processing of Power System Analysis Problems via Simple Parallel Microcomputer Structures", ibid., PAS-97, No. 5 (1978)
久 和

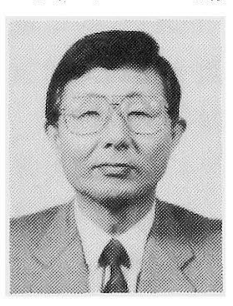

進（正員） 1949 年 6 月 22 日生。1972 年 3 月京都 大学工学部電気工学第 2 学科卒業。同年 4 月北 陸電力(株)入社。主として, 系統運用業務, 水 力開発計画業務, 通信業務などに従事。現在, 系統運用部通信課課長。
吉田忠美（正員） 1958 年 11 月 24 日生。1983 年 3 月慶応

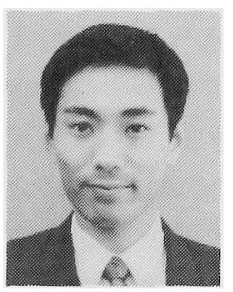
義塾大学大学院工学研究科電気工学専攻修士課 程修了。同年 4 月北陸電力 (株) 入社。主として, 電力系統運用に関する業務に從事。 
小俣 和也（正員） 1955 年 6 月 19 日生。1978年 3 月早稲 田大学理工学部電気工学科卒業。1980 年 3 月同 大学大学院理工学研究科修士課程修了。同年 4 月(株)東芝入社。以来, 重電技術研究所にて電 力系統の解析手法, 信頼度制御などの研究に従 事。

湯朝真司（正員） 1956 年1月13日生。1974年 3 月日田 林工高等学校電気科卒業。同年 4 月 (侏) 東芝入 社。以来, 電力系統の監視制御システムに関す る業務に従事。
三田村 謙 一 (正員) 1960 年 6 月 10 日生。1983 年 3 月広島 大学工学部第二類卒業。1 1985 年 3 月同大学大学 院システム工学研究科修士課程修了。同年 4 月 (株) 東芝入社。以来, 府中工場にて, 主として 電力系統の監視・制御システムの開発に従事。

80

$\&$

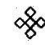

8

$\&$

$\&$ 